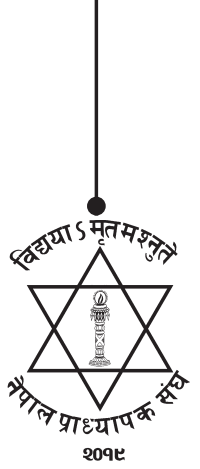

NJ: NUTA

\title{
Biodiversity Resources and Livelihoods: A Case from Lamabagar Village of Middle Nepal
}

\author{
Uttam Sagar Shrestha \\ Lecturer, Padhma Kanya Campus \\ Bagbazar, Kathmandu \\ Email for correspondence: usshrestha@yahoo.com
}

\begin{abstract}
The biodiversity resources are integral part of the livelihoods of residents of Lamabagar Village Development Committee. Over the last three decades, the number of species has been decreasing due to infrastructure developments- roads, hydropower's. Reportedly, 277 species of plants 24 species of mammals and 37 species of birds were recorded in 2003 has come down to 244 species of plants, 20 species of mammals and 32 species of birds only in the present study. It has led mis-balance between biodiversity conservation and livelihood strategy. The present paper tries to discuss on overview of plant and animal diversity between 2003-2012, common relationship between bio-diversity resources and their implication in the livelihood, conservation issues and their threats. The findings of the work are based on the fieldwork carried out field survey between 2003 and 2012.
\end{abstract}

Key words: Biodiversity, development interventions, plant species, mammals and agriculture.

\section{Introduction}

Biological Diversity in Nepal is closely linked to livelihoods of many people and their economic development, and touches upon agricultural productivity and sustainability, human health and nutrition, indigenous knowledge, gender equity, building materials, climate, water resources and aesthetic and cultural well being of the society (MOFSC, 2002). Therefore, in addition to terrestrial biodiversity, it also covers marine and other aquatic biodiversity as well. As such, biodiversity means richness and variety of living things in the world as a whole or any location within it. Biological resources include genetic resources, organism or parts thereof, populations or any other biotic component or ecosystems with actual or potential use or value for humanity.

Species diversity Change in relative abundance of species over an area or a distance is referred to as an ecological gradient. In mountainous areas, change in elevation led to same biographic change that occur with change in latitude (Botkin \& Keller, 2000). The complexity and Varity of living systems in the mountain region are not only limited to geographical distribution but also present extreme biological diversity in terms of ecosystems, species and genetics.A livelihood comprises the capabilities, assets (including both material and social resources) and activities required for a means of living. The livelihood of Lamabagar Village Development Committee (LVDC) has been maintained with resources extracted from various plant, animal and agro diversities. The indigenous people (Thamgni, Sherpa, Surel etc.) since long time dependent in the resources of bio-diversity. The occupation castes that have 
not other means of skill were involved in production and selling of vaarious goods extracted from bio goods in the bazaar.

\section{Materials and Methods}

The study is based on information collection on the field survey in the Lamabagar VDC 2012; the information was collected through KII, FGD and other methods. The study was concentrated on locations like Jagat (Ward, 9), Gonger (Ward, 5), Lamabagar (Wards, 2 \& 3), Lomnang/Lapche (Ward, 1). The total sample size for the study was 108 households which represent 27.41 percent. The information on biodiversity/bio resources collected through standard checklist and survey reports conducted by, Nor consult SWECO Norg, and data collected by the School of Environmental Science and Management (SchEMS), between 2003 and 2012. Moreover, Rapid Rural Appraisal (RRA) was organized to solicit the information on use of bio-diversity resources and their livelihood strategies on forest resources, extraction fishing business of herbs for income generation.

\section{Study Area}

The study area is located in Lamabagar VDC of Dolakha District, Janakpur Zone in the Central Development Region (CDR) of Nepal. Geographically it lies between the latitudes $28^{\circ} 10^{\prime} 00^{\prime \prime} \mathrm{N}$ and $27^{\circ} 50^{\prime} 00^{\prime \prime} \mathrm{N}$ and longitudes $86^{\circ} 15^{\prime} 00^{\prime \prime} \mathrm{E}$ and $86^{\circ} 05^{\prime} 00^{\prime \prime} \mathrm{E}$. The area is accessible from Kathmandu via $122 \mathrm{~km}$ long asphalt road up to Charikot bazaar and by another gravel road of $68 \mathrm{~km}$ up to Lamabagar

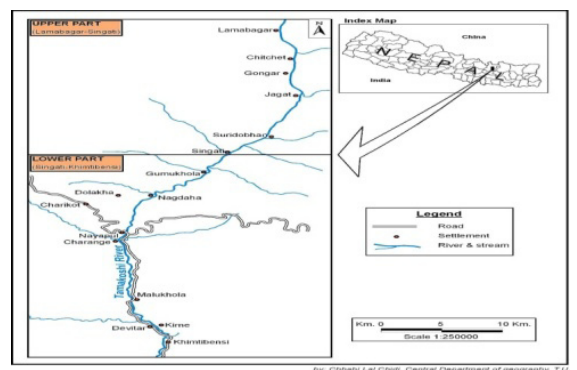

Figure 3. Location Map pf Study Area village. The study area comprises 1808 population with 394 households. Reportedly, the average family size of household is 4.58 person per household which is less than average household size of district 5.43. (CBS, 2004). The major settlements starts from Purano Jagat(1306 m.a.s.l) in the south to Lapche (2400 m.a.s.1). The other settlements are Lemenang, Thasina, Thansimu, Lumnang and most of these settlements are small in nature.

The study area is composed of many ethnic groups making up distinct communities according to altitude and climatic the latest information shows that the area is inhabited by 1080 persons and majority of them are dominated by Tamang (57.45\%), Sherpa (11.72\%), Dalit (4.70\%), etc.

The climatic variation is also varied in the corridor ranging cold in the upper part to temperate in the lower part. The maximum average temperature of the area is 190 Celsius and minimum 20 celsius (DHM and ICIMOD, 1996). GIS Map Analysis shows that the total area of the VDC is 2869 hect and major part of the area is covered by forest 48.93 percent followed by bush 16.85 percent. The sand, river and other category cover a total of 5.33 percent.

\section{Results and Discussions: Plant Diversity}

The area is rich in broad leaved- oak forests present along the river valley up to the Chinese border. The important species are quercus sp., Abies spectavilis, Acer sp., alnus nepalensis, Rhodoendron sp., (NEA, 2006). The dominant plant species found in the area are: Gobre salla, (Pinus wallichiana, Thingure salla (Tsuga dumosa), Chilaune (Schima wallichii), Uttis (Alnus nepalensis), Katus (Castanopsis tribuloides), Khasru (Quercus semicarpifolia), Champ (Michelia champaca), 
Kafal (Myrica esculenta), Painyu (Prunus cerasiodes), Bhalayo (Semecarpus anacardium), Dudhilo (Ficus nerifolia), Banmara(Chromolaena odorata), Chiraito (Swertia chirayita), SatuwaJatamasi (Nardostachys grandiflor), Panchanule (Dactylorhiza hatagirea, Bikhamoha (Acontium bishma) Sisnu (Urtica dioca) Nigalo

Altogether, 277 plant species has been recorded in the study belonging to 211 genera of 90 families. Among the recorded species there were 98 species of trees, 70 species of shrubs, 72 species of herbs and grasses, 15 species of climbers, 13 species of ferns and 9 species of orchids(NES,2003). However, the plant species found during the present study is limited only to 224 . The difference of the species with genera of different periods are listed in table below:

Table 1. Temporal Change in the Plant Species

\begin{tabular}{llll}
\hline Category of species & $\mathbf{2 0 0 3}^{*}$ & $\mathbf{2 0 0 8}^{* *}$ & $\mathbf{2 0 1 2 * * *}$ \\
\hline Plant species & 277 & 230 & 224 \\
Genera & 211 & 80 & 78 \\
Families & 90 & 82 & 80 \\
Tree species & 98 & 92 & 88 \\
Shrub species & 70 & 58 & 58 \\
Herbs and grass & 72 & 50 & 44 \\
Climbers & 90 & 14 & 12 \\
Ferns & & 11 & 11 \\
Orchid & 9 & 5 & 5 \\
\hline
\end{tabular}

(*NEA, 2006**ScHEMS, 2009*** Field Survey, 2012).

\section{Wildlife/Birds Diversity}

The major species found in the area Bagh, Bhalu Ghoral Mrigha Thar Jharal, Bandar. Different species recorded between 2006 to present study area presented below:

Table 2. Temporal Change in Faunal Species

\begin{tabular}{llll}
\hline Category of species & $\mathbf{2 0 0 3}$ & $\mathbf{2 0 0 8}$ & $\mathbf{2 0 1 2}$ \\
\hline Mammals & 22 & 24 & 20 \\
Birds & 46 & 37 & 32 \\
Fishes & & 3 & 3 \\
\hline
\end{tabular}

(*NEA, $2006 * *$ SchEMS, $2009 * * *$ Field Survey, 2012).

The other species are Redpanda, musk deer, Himalayan black beer, snow leopard, Jharal, and blue sheep. The commonly reported mammals are Barking deer (Muntiacus muntuik) Rhesus Monkey (Macaca mulata), Jackal (Canis aureus), Squirrel (Funanbulus sp.) and Langur (Macacca assamensis). Leopard (Panther pardus), squirrel (Funabulus) and Dumsi (Hystrix indica) also inhabit in the area. Reportedly,Himalayan bear (Selenarctos thibetanus) and Sloth bear (Melurus ursinus) are also found at higher ground. Altogether 22 mammals were reported near Lamabagar (Norconsult, 2006). Out of that 13 spices have been included in CITES categories under different Appendices .Similarly, Bwanso (Canis lupus)and Bhalu (Selenarctos thibetanus) are under the Vulnerable IUCN category and Thar (Nemorhaedus sumatraensis) is under the insufficiently known IUCN category But barking deer are found in the most of the community forestsAmong the 46 species of bird recorded in the study area, 8 species of birds are endangered and protected. 


\section{Birds Diversity}

The valley of Tamakoshi basin of Lamabagar VDC is important migratory route for birds that migrate from Koshi Tappu Wildlife Reserve (Ramsar site of Nepal) to Siberia and vice versa. The migration is popular during spring and autumn. The evergreen mixed broad leaf forest of the riverside ecosystem in the upper part area favors a variety of avifaunal species. Altogether 44 species of birds were reported in Lmabagar VDC (SWECO Norg, 2009). Among others, large attractive pheasant such as Danphe Lophophorus, Munal Trajapan saty are also found in the range.

\section{Fish species}

The study shows that the diversity of fish follows the common Nepalese pattern of progressively increasing towards downstream. Only three species like Schizothorax richardsonni (Asala) schozothorax annandalei (Asala) are found. There is significant variation in the river morphology causing restriction of the migratory fishes.

\section{Livelihood Strategy}

The people of study area depend on variety of livelihood strategy such as harvesting of forest products, livestock's, agricultural products, trade, wage level and most recently cash crops and tourism. But changing livelihood strategies have shown some king of change in the total composition of bio diversity resources. Livelihood are maintaining from making of leaf to collecting gum and seeds to hunting of wildlife etc. Such livelihoods generally, vary with seasons, forest, trees and CPRs support livestock's of local communities/groups in three ways (Chamber, Saxena \& Canway, 1991) (i.) providing for subsistence needs of fodder, fuel etc, (ii.) as source of income, and (iii.) as a capital goods or savings to be cut and encased to meet contingencies. The divisions of livelihood strategies are presented in following divisions:

\section{Plant Diversity and Livelihood}

Local people have been using various plants for fodder, firewood, food timber as well as medicinal value. The general description of use of plants for various purposes is presented below:

Table 3. Use of Floral Diversity for Livelihood

\begin{tabular}{|c|c|}
\hline Purposes & Plant Sepecies \\
\hline Fuel wood & Schima wallichii Chilaune(for fire wood) \\
\hline Fodder/Forage & $\begin{array}{l}\text { Alnus nepalensis Utis spicata Mauwa Ficus neriifoliaDudhilo, Kutmero(fodder used } \\
\text { for livestock during dry season) lyonia avalifolia anjeri, Rhus wallichii Bhalayo(for } \\
\text { fodder and rice feeding ceremony), like Bauhma, vahlii, Desmondum florvundum, } \\
\text { Desmodium, heterocarpan, Eurya acminate and inula cappa, erthring, vaircrgate, shorea } \\
\text { robusta, utise minapetalna and queerdus and ficus Sughandhiwala Valeriana wallichii } \\
\text { Dhupipat Cryptomeria japonica,Silajit, Jhau Bhir maha Ghobreshall leaf, Bankerela }\end{array}$ \\
\hline Handmade paper & Lokta (Dhaphane Bhauluwa) and Argeli ( Sureil) \\
\hline Medicinal Plants & $\begin{array}{l}\text { Charito (Sweritia Chirayita), Amala (Phylllanthus emblica), Laut Salla (Taxus baccata), } \\
\text { Jhau (Lichens) and Kurilo(Asparagus sp ) }\end{array}$ \\
\hline Timber & Shorea robusta Sal,DursulTerminalia alata Sa \\
\hline $\begin{array}{l}\text { Religious } \\
\text { purposes }\end{array}$ & Bhalayo \\
\hline Food/fruits & kaphal, katus, jamun amala chuk, tusa, taama \\
\hline Commercial use & Amriso and Allo \\
\hline
\end{tabular}

(Field Survey, 2012).

NUTA JOURNAL, 6 (1\&2), 2075 : ISSN: 2616 - 017x 
People in three settlements of Lamabagar VDC consider community forest as the major source of their timber and Non Timber Products. Timber, firewood, fodder is obtained in more amounts from the community forest of Lamabagar and surrounding settlements, whereas, in other settlements people collects these products from national forest and surrounding fields. In total the use of forest, products as fuel wood was records highest (98.3\%). On average $2300 \mathrm{~kg}$ of fuel wood was used per household per year during 2008. This is equivalent to about 450 per $\mathrm{kg}$ of fuel wood per household in a $\mathrm{HH}$. Fuel wood use in immediate south of the settlement is lower, which is $280 \mathrm{~kg} /$ person/year. Of different sources of fuel wood hey usually collected about 386 MT (56.3\%) fuel wood from the community forest. Still major person of study are dependent in the forest for firewood. Fuel wood is dominating for cooking and for heating space, cooking etc. The plants like uttis, chaulauni, khashru, phalat, oak, bsasr, gobresallo, thingr shallo etc are abundant and they use it for firewood and trading also. The average firewood use per household is equivalent to 3 to 5 bhari ( equivalent to $180 \mathrm{~kg}$ to $300 \mathrm{~kg}$ ) The introduction of bio gas in Puano jagat has made some kind of changes in the use of firewood but still majority of people use fuel for Kundo cooking.

\section{Herbs/Medicinal Value}

Formerly local people were more enact with use of bio -diversity resources to cure diseases like Jundice, Pinas, Chhare Rog, white dubii. ganorrea, sterile. sugar, pressure, gyasticpiles, cought etc. Even the local female also used local agricultural pesticides and herbicides. They are expert in the edibles and non edible foods like mushrooms, kuriol, yam, etc. Sherpa, Tamang, Chhetri Thakuri etc. are directly or indirectly derived their livelihood resources from trading herbal goods even Kasturi beena. Formerly, people from the higher part (Lapcha, Lamabagar) come down to lower part (Khurkot, Ghurmi of Sindhuplachowk) with herbs and animal product. They usually do barter with food grains, dried vegetables.

Although a number of plants are used for healing ailments and illness, 34 important plants species were reported from the study area. Among them some medicinal palnts like Charito (Sweritia Chirayita), Amala (Phylllanthus emblica), Laut salla (Taxus baccata), Jhau (Lichens) and Kurilo (Asparagus sp) are exported to the south. It is reported that 24 different types of medicinal plants and their products are exported from the study area and by which one person earn more than 20 to 25,000 per year. Informal discussions with local people told that about a total of NRs.100000 business are held under the herbs. At present the mediators come to for collection of the herbs. The herbs like red mushroom, Binaune, Bojho, Satuwa Gainu sell at the cost of Rs. 1500 per Kg. The persons who are involved in Panchaule Yarsha Gomba and business earn more than NRs.4 lack per year.

Allo Sisnu (Giradina palmanuts) seem as heavily medicinal value in locality. People make powered from its leaves and consumed it as a soup. The powder is also sold in the local market by groups of unemployed people, mostly Thamis' and disadvantaged group of people. The cost of powder is NRs. 300 per kg. The cloths from the allo is famous and sold in high price even in the Dolakha market at the cost of Rs. 700 per piece. Reportedly 60 percent of households of the study area involved in it and earns 15,000 to 25,000 per household per year.

\section{Agro Diversity and Livelihood}

Studies have shown that agro ecosystems located in the natural resource in locality rich areas are generally more energy efficient than there located in resource poor areas of mountains). Mountain societies are dependent in traditional complex species agro ecosystem organized in space and time. Maize, 
Millet, Wheat, Potato and Barley (Uwa) are the major cultivated crops. The production of potato is higher in the area (14.93 ton in 5.08 Ha). The least produced crop is Millet (0.19 ton in 0.51 Ha).Maize and potatoes are common Lamabagar, barley in Lapche and small percentage of rice are cultivated in lower part near Jagat. Out of total household in the upper part 28.08 percent reported sufficiency throughout the year. Of the total sample area, $23.6 \%, 35.65 \%$ and $12.65 \%$ household reported sufficiency of food for 9-12 months, 6-9 months, and 3-6 months respectively (Norconsult, 2006).

\section{Livestock}

The major types of livestock in the study area are goat (15\%), cow $(15 \%)$, buffalo ( $10 \%)$ sheep (15\%), Chaurie (30\%) and yak (15\%). Out of total livestock dominated $60 \%$ is chauri in area. FGD with local people inform that at least one household sell 2-5 livestock specially goat, in the local area each year.

\section{Livelihood from Fishing}

The gross income of the family by selling the fish is equivalent to NRs. 14,125 . Reportedly 46 per cent or 22 houses sell less than $50 \mathrm{~kg}$ in the month and $18 \mathrm{hh}(37.7 \%)$ household sells between 50 $-100 \mathrm{~kg}$ and only $89.17 \%$ households sells more than $100 \mathrm{~kg}$ per month (Shrestha, 2010).

\section{Income}

The income of household in the study area composed of sources like, income from forest, wild life, agriculture, animal husbandry, and tourism. The average annual income of the areas is estimated to 104,452 . The main sources of income are forestry, agriculture and animal husbandry which contribute $43.5 \%$ to the average annual income (Norconsult, 2006).

\section{Issues and Threats: Hunting /Poaching/Smuggling}

From the interview with local people it has been found that hunting and poaching is common in the study area. Reportedly, wild animal have been killed by using paso, trapping shooting and other techniques. The other techniques used for killing wild animal are digging trap hold in a known animal route (used for porcupine) and use of smoke in dens and nests. Dogs are also used to locate fresh dens of porcupines. The local people reported increase in kalij peasant during insurgency period mainly due to banning of guns. People do not sell meet in the market but they do hunting to supply meat in the family. However, children were found to be involved in hunting activities basically for hunting kalij pheasants. These hunters do not have hunting license but they do hunt and sell them at the rate of NRs. 1000-2000 per kaliz in the local market who usually pay for this item at high price. At least 15-20 persons are usually getting good income from selling. Most of the animal species are common in the in near by area except otter which was apparently heavily trapped by gypsies (Banjare, Nepali for gypsy) from India who frequently visited the area 5-10 years back. The ghoral occurrence as generally in the mountain areas. Local people also use hides of wild animal like deer, bear and jackle as mattresses. The purpose of hunting and poaching are presented below:

Table 5. Faunal Diversity and its Hunting/Poaching to Support Livelihood

\begin{tabular}{ll}
\hline Purposes & Faunal Sepecies \\
\hline Meat & Ghoral, Mirga, Jharal, Habre, Kasturi, Dumsi \\
Skin & Bagh \\
Bone & Bagh \\
Others & Bhalu, Bandar, Thar \\
\hline
\end{tabular}

(Field Survey, 2012).

NUTA JOURNAL, 6 (1\&2), 2075 : ISSN: 2616 - 017x 


\section{Livestock Loss by Wild Predators}

Livestock are more threat to wild predicators in the study area. The main prediators are leopard, wild cat, jackal, common mongoose.and yellow throated marten. The FGD indicated usually around $10-20$ domestic animals are killed by wild animals each year.

\section{Crop Loss due to Wildlife}

The FGD reported monkeys, Hanuman langur, and porcupine and barking deer, Kalij are the main animals and birds damaging crops in the study area. There is considerable wildlife movement including the cross of river movement in the study area. The maize, wheat and potatoes are important crops damaged by these animals. Altogether around 100 households' losses their crops from wild animals among which monkeys were the key pests in the area. According to the local estimate around 75 percent crop is damaged by monkey followed by deer 15 percent and rest 10 percent by klij, jackl, dumsi and wolf. Among the crops major crops damage by animals were maize 55\%, millet 15\%, paddy $10 \%$ and rest potatoes, wheat, vegetables etc.

\section{Wildlife Movement Across the Tamakoshi River}

Wild animals generally move across fragmented forest patches and agricultural land in search of food within their home range. The home range varies according to wildlife species. Sometimes human disturbance may cause animals to go far from their own habitats. Local people informed that sometime people chase monkeys to other areas far from their agricultural land. The solitary wild animals move a long distance specially predators such as leopard. It is reported that leopards use south face hill forests during winter season and north face hill forests during summer seasons.

\section{Development Intervention}

The development intervention has risen within the last three decades in the study area. The road from Charikot to Singati (1986/87), is the landmark threatening to disappearances of biodiversity. The other major development activities are:

- On going road construction of road up to Gonger and further development towards boarder village, Lapchee.

- Opening road to each VDC destroying national/religious and community forest

- Number of large, medium and small hydropower projects like Spring HP, Singati Khola, HP Khare Khola HP etc.

\section{Conclusion}

Conservation of biodiversity and maintaining the livelihood strategy is complex. The local people trying to maintain the livelihood through using biodiversity resources to their livelihood strategy. The number of biodiversity species which were dominant for livelihood has been decreasing with time (2003 to 2012) from 277 species to 244 species of plants, 24 species to 20 species of mammals and 27 species to 32 species of birds. The development activities especially the hydropower and road is responsible for decreasing the biodiversity. But question remain over here is how to sustain livelihood with changing situation biodiversity. The debate is equally vibrant not only to the case of study area but in the case of other river basin or watersheds too. Thus, this paper concludes by how government makes vibrant way to make conservation of biodiversity and livelihood support program. 


\section{Acknowledgements}

The author would like to express gratitude to Dr. R. B. Khadka, Principle, SchEMS, Mr. Ramesh Shakya, Joint Secretary, Ministry of Forest and Soil Conservation for providing support to field visit and related data and Mr. Uddab Khadka, ScHEMS for providing resources, necessary information of study area.

\section{References}

Botkin, D. B. \& Keller E. A. (2000). Environmental Science Earth as a Living Plane New York, Chchesteer, Weinheim, Brisbane, Singapoore, Toronto, John wiley ans sons, Inc.,

CBS (2004). Population of Nepal, Village Development Committees/Municipality Population Census, Kathmandu, Central Bureau of Statistics

Chambers, R. \& Conway, G. R. (1991). Sustainable Rural Livelihoods; Practicall Concepts for 21 st. Century (Discussion Paper 296). Brigton; Institute of Development Studies (IDS)

DDC (2001). District Profile of Dolakha District, Dolakha District Development Committee, District Information Centre,

Department of Hydrology and Metrology (DHM)/(ICIMOD). (1996). Climatic and Hydrological Atlas of Nepal, Kathmandu: ICIMOD/DHM, Nepal.

MOFC/Nepal (2002). Nepal Biodiversity Strategy, Kathmandu, HMG/N/MOFC, Supported by Global Environmental Facility and UNDP

NEA (2006). Environmental Impact Assessment Report of Upper Tamakosh Hydroelectric Project, Kathmandu, Unpublished report

Norconsult (2006). Environmental Impact Assessment Report of Upper Tamakosh Hydroelectric Project, Kathmandu, Unpublished Reports.

Shrestha, U. S. (2010). Livelihood Pattern of Majhi Community in th tamakoshi River Basin. In P. K. Pradhan et al., (Eds.) Environment, Livelihood and Microenterprises. Kathmandu: Central Department of Geography

SN Power \& SchEMs (2008). Baseline Study of Tmakoshi II and Tamakoshi III Hydropower Project, School of Environmental Science and Sustainable Developments (SchEMS) \&SN/ Power holding Pte. Ltd Kathmandu, Unpublished document

Sweco Norg (2009). Tamakoshi 3 Hydroelectric project, Executive Summary-Vol XI Document for Discloser ,SWECO Norg As, Oslo Norway 